\title{
Production of reactive oxygen species in macrophages treated with essential oil of Croton argyrophyllus Kunth
}

\author{
Silvan Araújo ${ }^{1}$, Aline Oliveira ${ }^{* *}$, Matheus Santos', Sandra Santos ${ }^{1}$, Jamile Ferro ${ }^{2}$, Emiliano Barreto², \\ Alexandre Cândido ${ }^{3}$, Brancilene Araujo ${ }^{1}$, Angelo Antoniolli ${ }^{1}$, Charles Estevam ${ }^{1}$ \\ From 5th Congress of the Brazilian Biotechnology Society (SBBIOTEC) \\ Florianópolis, Brazil. 10-14 November 2013
}

\section{Background}

Essential oils are complex systems which consist mainly of volatile compounds of lipophilic source, as terpenes, sesquiterpenes and some non-terpenes [1]. Resulting from secondary metabolism, essential oil from Croton argyrophyllus (EOCA) is commonly extracted from its leaves. It is known that the essential oils from Croton species exhibit good antioxidant activity against DPPH free radical and reactive oxygen species (ROS) [2]. Several diseases are attributed to the increase of free radicals that show the importance of endogenous antioxidants like enzyme superoxide dismutase (SOD). Considering the use in folk medicine, it is relevant to find which concentration of EOCA has antioxidant effect against free radicals. To answer this question, the study aimed to evaluate ROS production in peritoneal macrophages of essential oil from C. argyrophyllus.

\section{Methods}

After collection in the field, the essential oil from leaves of C. argyrophyllus was extracted by hydrodistillation method using apparatus of the type Clevenger having a yeld of $0,5 \%$. Male Swiss mice $(n=5)$ that were 8 weeks old were used. All procedures were approved by and followed the guidelines of the institutional ethics committee on animal research at Federal University of Sergipe. After being sacrificed, were injected $10 \mathrm{~mL}$ PBS, then after vigorous massage was obtained peritoneal exudate. The macrophages were prepared in 96-well plate, $10 \mu \mathrm{L} /$ well NBT $(2.0 \mathrm{mg} /$ $\mathrm{mL})$ and EOCA in different concentrations $(5,10,25,50$ and $100 \mu \mathrm{g} / \mathrm{mL}$ ) [3]. NBT reduction was measured in

Physiology Department, Sergipe Federal University, São Cristóvão, SE, Brazil Full list of author information is available at the end of the article response to zymosan $(250 \mu \mathrm{g} / \mathrm{mL}$ in $\mathrm{RPMI})$. Next, the micro plate was incubated at $37^{\circ} \mathrm{C}$ for 120 minutes, and the reaction was stopped by discarding the supernatant. The sediment was resuspended by addition of $120 \mu \mathrm{L}$ $\mathrm{DMSO} / 80 \mu \mathrm{L} \mathrm{KOH} \mathrm{(2M)} \mathrm{in} \mathrm{each} \mathrm{well.} \mathrm{The} \mathrm{results} \mathrm{were}$ obtained in micro plate ELISA reader using as a blank the NBT in wells with unstimulated cells. The optical density $\left(\mathrm{OD}_{630 \mathrm{~nm}}\right)$ of formazan produced (insoluble blue deposit) was directly proportional to the ROS generated by phagocyte combined with a lower activity of the enzyme SOD. The data were subjected to variance analysis (ANOVA), with Tukey post hoc. The data variation were tested in triplicate and the differences considered statistically significant when $\mathrm{p}<0.05$.

\section{Results and conclusions}

Some sesquiterpenes found in the composition of the EOCA have proven antioxidant activity such as bicyclogermacrene [4]. In the NBT test, the EOCA concentrations from $10 \mu \mathrm{g} / \mathrm{mL}$ to $100 \mu \mathrm{g} / \mathrm{mL}$ showed inhibitory activity of SOD and consequently generated more ROS. Thus, the concentration $5 \mu \mathrm{g} / \mathrm{mL}$ was the most effective, both in comparison with the blank and the negative control (Zy). It was concluded that the lower concentrations of $10 \mu \mathrm{g} /$ $\mathrm{mL}$ have antioxidant activities and therefore it is suggested cellular protection against free radicals.

\section{Acknowledgements \\ We would like to thank Dra Ana Paula Prata for the botanical identification of the species. \\ Authors' details \\ 'Physiology Department, Sergipe Federal University, São Cristóvão, SE, Brazil. \\ ${ }^{2}$ Institute of Biological Science and Health, Alagoas Federal University,}


Maceió, AL, Brazil. ${ }^{3}$ Morphology Department, Sergipe Federal University, São Cristóvão, SE, Brazil.

Published: 1 October 2014

\section{References}

1. Castro HG, Oliveira LO, Ferreira FA, Silva DJH, Mosquim PR, Nascimento EA: Teor e composição do óleo essencial de cinco acessos de mentrasto. Quím. Nova 2004, 27:55-57.

2. Morais SM, Catunda Júnior FEA, Silva ARA, Martins Neto JS, Rondina D, Cardoso JHL: Atividade antioxidante de óleos essenciais de espécies de Croton do Nordeste do Brasil. Quím Nova 2006, 29:907-910.

3. Rook G, Steele J, Umar S, Dockrell H: A simple method for the solubilisation of reduced NB and its use as a colorimetric assay for activation of human macrophages by g-interferon. $J$ Immunol Methods 1985, 82:161-167.

4. Almeida TS, Rocha JBT, Rodrigues FFG, Campos AR, Costa JGM: Chemical composition, antibacterial and antibiotic modulatory effect of Croton campestris essential oils. Ind Crop Prod 2013, 44:630-633.

doi:10.1186/1753-6561-8-S4-P255

Cite this article as: Araújo et al.: Production of reactive oxygen species in macrophages treated with essential oil of Croton argyrophyllus Kunth. BMC Proceedings 2014 8(Suppl 4):P255.

\section{Submit your next manuscript to BioMed Central} and take full advantage of:

- Convenient online submission

- Thorough peer review

- No space constraints or color figure charges

- Immediate publication on acceptance

- Inclusion in PubMed, CAS, Scopus and Google Scholar

- Research which is freely available for redistribution

Submit your manuscript at www.biomedcentral.com/submit 